\title{
Faktor yang Mempengaruhi Produksi Usahatani Jagung di Desa Lorotolus Kecamatan Wewiku Kabupaten Malaka
}

\author{
Adrianus Seran Kolik ${ }^{\mathbf{a}}$, Simon Juan Kune \\ ${ }^{a}$ Fakultas Pertanian, Universitas Timor, TTU-NTT, Indonesia. Email: adrianuskolik@gmail.com \\ ${ }^{b}$ Fakultas Pertanian, Universitas Timor, TTU-NTT, Indonesia. Email: Simon_Kune@faperta-unimor.id
}

Article Info

\section{Article history:}

Received 20 Februari 2019

Received in revised form 15 Maret 2019

Accepted 16 April 2019

DOI:

https://doi.org/10.32938/ag.v4i2.524

Keywords:

Jagung

Cobb-Douglass

Produksi

\section{Pendahuluan}

Pembangunan sektor pertanian merupakan bagian yang sangat penting bagi perekonomian Indonesia. Peranan sektor pertanian antara lain meningkatkan pendapatan taraf hidup petani dan nelayan, memperluas lapangan kerja dan kesempatan usaha, serta mengisi dan memperluas pasar, baik pasar dalam negeri maupun pasar - pasar luar negeri. Salah satu sektor pertanian yang cukup baik adalah sub sektor tanaman pangan (Cahyadinata, 2010)

Menurut data dari Dinas pertanian tanaman pangan Kabupaten Malaka, produksi jagung berfluktuasi selama tiga tahun terakhir, pada tahun 2013 luas panen $14.859 \mathrm{Ha}$, dan produksinya 40.591 ton, tahun 2014 luas panen 21.821 Ha, produksinya 52.414 ton, dan tahun 2015 luas panen $21.387 \mathrm{Ha}$ produksinya 51.370 ton (Badan Pusat Statistik Malaka 2014).

Masyarakat Desa Lorotolus pada umumnya mengusahakan usahatan jagung dan mereka menggantungkan hidup mereka pada hasil pertanian yang dihasilkan, demi memenuhi taraf kebutuhan hidup sehari - hari. Menurut data Dinas Pertanian Tanaman Pangan Kabupaten Malaka Produksi jagung di Desa Lorotolus mengalami fluktuasi, sehingga pada tahun 2012 luas panen $79 \mathrm{Ha}$ rata-rata produksi 2,6 Kw/Ha, dan produksinya 205 ton, tahun 2013 luas panen $140 \mathrm{Ha}$, rata-rata produksi $3 \mathrm{Kw} / \mathrm{Ha}$ dan produksinya 420 ton, pada tahun 2014 luas panen $140 \mathrm{Ha}$, rata-rata Produksi $3 \mathrm{Kw} / \mathrm{Ha}$ dan produksinya 420 ton (Dinas Pertanian Tanaman Pangan Kabupaten Malaka 2014).

\section{Metode}

Penelitian dilaksanakan pada bulan Februari-Juli 2018 di Desa Lorotolus karena merupakan salah satu desa yang berada di Kecamatan Wewiku yang memiliki sentra produksi jagung. Pengambilan data yang digunakan dalam penelitian ini dengan cara survei. Pemilihan sampel dilihat dari petani yang mengusahatani jagung, jadi menggunakan Rumus Slovin sebagai pengambilan Sampel.

Untuk mengetahui gambaran usahatani jagung di Desa lorotolus Kecamatan Wewiku Kabupaten Malaka digunakan analisis deskriptif kualitatif sedangkan untuk mengetahui faktor-faktor produksi yang mempengaruh produksi jagung digunakan analisis regresi berganda dalam bentuk fungs bentuk produksi Cobb-Douglas ssebagai berikut: Soekartawi (2003) mendefinisikan fungsi produksi Cobb-Douglas adalah suatu fungsi atau persamaan yang melibatkan dua atau lebih variabel, dimana variabel yang satu disebut dengan variabel dependen, yang dijelaskan (Y) dan yang lain disebut variabel independent, yang menjelaskan $(X)$. Penyelesaian hubungan antara $Y$ dan $\mathrm{X}$ adalah bisa dengan cara regresi dimana variasi dari $\mathrm{Y}$ akan dipengaruh oleh variasi dari X. Dengan demikian kaidah pada garis regresi juga berlaku dalam penyesaian fungsi cobb doglass.

Secara matematik, fungsi Cobb-Douglas tersebut dinyatakan oleh hubungan Y dan X maka :

$$
Y=A X_{1}^{b 1}, X_{2}^{b 2}, \ldots \ldots . X_{n}^{b n} e^{u}
$$

Bila fungsi Cobb-Douglas tersebut dinyatakan oleh hubungan $\mathrm{Y}$ dan $\mathrm{X}$ maka diubah menjadi bentuk linier berganda dengan cara melogaritmakan persamaan tersebut:

$$
L_{n} Y=A+b_{1} L_{n} X_{1}+b_{2} L_{n} X_{2}+b_{3} L_{n} X_{3}+b_{4} L_{n} X_{4}+b_{5} L_{n} X_{5}+e .
$$

Dimana :

$\mathrm{Y}=$ Jumlah produksi jagung $(\mathrm{Kg})$

$\mathrm{X}_{1}=$ Luas lahan $(\mathrm{Ha})$

$\mathrm{X}_{2}=$ Tenaga kerja $(\mathrm{HKO})$

$\mathrm{X}_{3}=\operatorname{Benih}(\mathrm{Kg})$
$\mathrm{X}_{4}=$ Pengalaman usahatani (tahun)
$\mathrm{X}_{5}=$ Pendidikan (tahun)
$\mathrm{A}=$ Intersep
$\mathrm{e} \quad=$ Kesalahan penggangu (disturbance term)
$\mathrm{b}_{\mathrm{i}} \quad=$ Koefisien regresi faktor produksi ke-i $(\mathrm{i}=1,2,3,4,5)$,
Ln = Logaritma natural : 2,7182 (Gujarati,2003).

\section{Hasil dan Pembahasan}

\subsection{Gambaran Umum Usahatani di Desa Lorotolus}

Pengolahan berada pada dua daerah penelitian yaitu daerah Harani dan daerah Haemuti, dimana pengolahannya dengan cara yang sama yaitu sebagian lahan menggunakan traktor dan sebagian menggunakan pacul dan linggis. Benih jagung yang digunakan petani desa lorotolus yaitu benih jagung lokal. Penanaman yang dilakukan di Desa Lorotolus yaitu secara manual dimana petani melubangi tanah dan memasukan 3-4 biji jagung pada lahan yang tersedia. Penyiangan dilakukan oleh petani 1-3 kali sesuai dengan keadaan gulma yang ada pada lahan, penyiangan dilakukan apabila tanaman sudah tumbuh 5-6 helai daun. Pemanenan dilakukan setelah jagung mencapai umur panen yaitu 3-4 bulan setelah tanam. Penanganan pasca panen dilakukan dengan cara pengeringan, pada umumnya dilakukan dengan penghamparan jagung dibawah sinar matahari menggunakan tikar atau terpal.

3.2. Faktor Yang Mempengaruhi Produksi Usahatani Jagung di Desa Lorotolus

Faktor yang dijabarkan dalam bentuk variabel yakni variabel bebas $(\mathrm{X})$ yang mempengaruhi variabel terikat $(\mathrm{Y})$. Dalam penelitian ini terdapat 5 (lima) variabel bebas $(\mathrm{X})$ yakni $\left(\mathrm{X}_{1}\right)$ luas lahan, $\left(\mathrm{X}_{2}\right)$ jumlah benih, $\left(\mathrm{X}_{3}\right)$ jumlah tenaga kerja, $\left(\mathrm{X}_{4}\right)$ pengalaman tenaga kerja, $\left(\mathrm{X}_{5}\right)$ lama pendidikan, yang mempengaruhi (Y) jumlah produksi jagung di Desa Lorotulus.

$Y=1.246+0.044 X_{1}+0.729 X_{2}+0.4 X_{3}-0.026 X_{4}+0.022 X_{5}$

Tabel 1. Hasil Persamaan Faktor Produksi Jagung di Desa Lorotulus

\begin{tabular}{llll}
\hline Variabel & Koefisien & t-Statistic & Prob. \\
\hline C & 1.246 & 5.368 & .000 \\
X1 & .044 & .982 & .329 \\
X2 & .729 & 8.047 & $.000^{\mathrm{a}}$ \\
X3 & .400 & 2.762 & $.007^{\mathrm{b}}$ \\
X4 & -.026 & -.340 & .735 \\
X5 & .022 & .399 & .691 \\
R-squared & 0,892 & & \\
Prob(F-statistic) & 0,093 & & \\
\hline
\end{tabular}

Keterangan : a dan b signifikan pada $\alpha$ : 0,01 dan 0,05

3.3. Interpretasi Hasil Analisis Faktor Produksi Jagung Desa Lorotolus. Luas lahan mempunyai pengaruh yang positif dengan nilai 0,044 . In berarti jika luas lahan meningkat $1 \%$ menyebabkan jumlah produksi jagung meningkat sebesar 0,044 persen. Sipayung (2015) luas lahan mempunyai pengaruh yang positif terhadap produksi.

Jumlah benih berpengaruh secara positif terhadap produksi jagung dengan nilai 0,729 . Ini menunjukkan bahwa jika jumlah benih meningkat $1 \%$ menyebabkan jumlah produksi jagung meningkat sebesar 0,729 persen. Sejalan dengan penelitian Bantaika (2017)

Jumlah tenaga kerja mempunyai pengaruh secara positif dengan produksi jagung Desa Lorotulus dengan nilai 0,40. Angka tersebut memiliki arti jika tenaga kerja meningkat $1 \%$ maka terjadi peningkatan produksi sebesar $0,40 \%$. Tenaga kerja berpengaaruh nyata terhadap produksi jagung, sesuai dengan hasil penelitian Budiono et al. (2012) dan Remedy (2015). 
Pengalaman berusahatani berpengaruh negatif terhadap produksi jagung dengan nilai -0.26 . Hal ini menunjukkan jika pengalaman meningkat $1 \%$ maka produksi jagung menurun 0,26 persen.

Lama pendidikan mempunyai pengaruh positif terhadap produksi jagung dengan nilai 0,22 . Ini berarti jika lama pendidikan meningkat sebesar $1 \%$ maka produksi jagung meningkat sebesar $0,22 \%$.

\section{Koefisien Determinasi $\left(\mathbf{R}^{2}\right)$}

Koefisien determinasi ialah variabel terikat $(\mathrm{Y})$ yang mampu dijelaskan oleh seluruh variabel bebas (X) dalam model nilai koefisien determinasi merupakan perbandingan antara jumlah kuadrat regresi dengan kuadrat total. Dari Tabel 1 dikatakan bahwa faktor luas lahan, benih, tenaga kerja, pengalaman dan pendidikan memiliki pengaruh sebesar $89,2 \%$ terhadap produksi usahatani jagung, sisanya sebesar 10,8\% dipengaruhi oleh faktor lain yang tidak diteliti dalam penelitian ini.

\section{Uji Simultan atau Secara Serempak.}

Uji $\mathrm{F}$ adalah untuk mengetahui apakah variabel bebas dalam model persamaan faktor produksi jagung Desa Lorotulus memiliki pengaruh secara bersama-sama terhadap variabel terikat. Variabel bebas yaitu luas lahan, jumlah benih, jumlah tenaga kerja, pengalaman usahatani, dan lama pendidikan. Pada Tabel 1 dapat dilihat dari probabilitas $F$ hitung 0,093. Variabel bebas berpengaruh nyata terhadap variabel terikat dengan $\alpha=10 \%$.

\section{Simpulan}

Pengolahan lahan; biasanya dilakukan pada musim kemarau yaitu berkisar bulan agustus-oktober. Pengolahan lahan terdapat pada dua daerah yaitu: daerah Harani dan daerah Haemuti. 2) Pemilihan benih; ada dua jenis benih jagung yang digunakan petani desa lorotolus yaitu benih jagung lokal 3) Penanaman; penanaman jagung dilakukan pada saat awal turunya musim hujan yaitu berkisar antara bulan november atau desember. Kegiatan penanaman di lokasi penelitian dilakukan secara tradisional, yakni petani melakukan penanaman menggunakan tugal kemudian dimasukan 3-4 biji jagung. 4). Penyiangan; penyiangan dilakukan oleh petani 1-3 kali sesuai dengan keadaan gulma yang ada pada lahan, penyiangan dilakukan apabila tanaman sudah tumbuh 5-6 helai daun. Kegiatan penyiangan dilakukan sehingga dapat menekan pertumbuhan pada tanaman gulma dan mempercepat tanaman jagung agar tidak terjadi perebutan unsur hara antara jagung dengan gulma. 5) Panen; pemanenan dilakukan setelah jagung mencapai umur panen yaitu 3-4 bulan setelah tanam. Pemanenan dilakukan apabila jagung sudah tua dan kulit sudah kuning dan mengering dan pemanenan yang dilakukan di lokasi penelitian secara tradisional atau manual yaitu jagung dipatahkan lalu dikumpulkan dan disusun didalam karung. 6) Pasca panen; penanganan pasca panen dilakukan dengan cara pengeringan, pada umumnya dilakukan dengan penghamparan jagung dibawah sinar matahari menggunakan tikar atau terpal. Pada waktu cerahnya matahari penjemuran dilakukan selama $2-3$ hari.

Faktor yang mempengaruhi produksi jagung secara signifikan adalah jumlah benih dan jumlah tenaga kerja. Luas lahan dan lama pendidikan memiliki pengaruh yang positif.

\section{Pustaka}

Badan Pusat Statistik.2014. Kabupaten Malaka Dalam Angka. Badan Pusat Statistik. Kabupaten Malaka.

Bantaika,Yuliana.2017. Faktor-Faktor yang Mempengaruhi Produksi Usahatani Jagung di Desa Tesi Ayofanu Kecamatan Kie Kabupaten Timor Tengah Selatan. Jurnal. Agrimor Vol. 2 (1) :10-11.

Budiono, A.,Wilda, K dan Yanti,DN. 2012. Analisa Faktor-Faktor yang Mempengaruhi Produksi Jagung di Kecamatan Batu Ampar Kabupaten Tanah Laut. Jurnal. Agribisnis Pedesaan Vol. 2 (2) :159-171.

Cahyadinata, Indra.2010. Kajian Produksi Jagung dan Faktor-faktor yang Mempengaruhinya (Studi Kasus di Kabupaten Seluma Provinsi Bengkulu). Universitas Bengkulu.

Dinas Pertanian Tanaman Pangan.2015. Data Produksi Desa Lorotolus. Dinas Pertanian. Kabupaten Malaka

Gujarati N. Damodar. 2003. Basic Econometric, Fourt Edition. New York: McGraw-Hill.

Remedy,Taufiq.2015.Analisis Faktor-Faktor yang Mempengaruhi Produksi Jagung ( Studi Kasus: di Kecamatan Mranggen Kabupaten Demak). Skripsi, Jurusan Ilmu Ekonomi dan Studi Pembangunan Fakultas Ekonomi dan Bisnis Universitas Diponegoro. Semarang.

Sipayung,Boanerges.2015.Analisis Faktor Penawaran dan Permintaan Kentang di Provinsi Sumatera Utara. Tesis, Program Magister Agribisnis Universitas Sumatera Utara. Medan.

Soekartawi, A.,1990.Teori Ekonomi Produksi Dengan Pokok Bahasan Analisis Fungsi Cobb Douglas.CV. Rajawali, Jakarta. 